\title{
Remission of genital and generalised extragenital lichen sclerosus et atrophicus under pulse therapy with intravenous steroids
}

\author{
Kerasia-Maria Plachouri, ${ }^{1}$ Francesk Mulita \\ Sophia Georgiou ${ }^{1}$
}

'Dermatology Department, University General Hospital of Patras, Patras, Greece ${ }^{2}$ Department of General Surgery, University General Hospital of Patras Holy Mary the Help, Patras, Greece

\section{Correspondence to} Francesk Mulita; oknarfmulita@hotmail.com

Accepted 20 April 2021

Check for updates

(c) BMJ Publishing Group Limited 2021. No commercial re-use. See rights and permissions. Published by BMJ.

To cite: Plachouri K-M, Mulita F, Grafanaki K, et al. BMJ Case Rep

2021:14:e241900

doi:10.1136/bcr-2021

241900

\section{DESCRIPTION}

A 57-year-old female Caucasian patient presented in our department due to intense pruritic patches with erythematous, brown and porcelain-white areas with prominent epidermal atrophy over the breast and abdominal area (figure 1A), the upper and lower area of the back as well as the proximal upper and lower extremities. The patient also presented with pruritic white plaques in the genital mucosa (introitus vaginae and labia majora). The lesions had first appeared 2 years prior to the referral and were gradually worsening in terms of size and pruritic discomfort. The patient denied receiving any treatment for her condition in the past and apart from Hashimoto's thyroiditis was otherwise healthy. The histological examination of a trunk lesion revealed findings compatible with lichen sclerosus et atrophicus (LSA). Due to the generalised cutaneous symptoms, we opted for a therapy with intravenous methylprednisolone $(1000 \mathrm{mg}$ in $250 \mathrm{~mL}$ dextrose) over 3 consecutive days every 4 weeks, over a period of 6 months. In the interval periods between treatments, the patient was advised to apply a clobetasol propionate $0.05 \%$ ointment once daily in the genital lesions, which was to be tapered according to the most current guidelines: once daily for the first month, every 2 days over the second month, two times per week over the third month, once a week over the fifth month and then therapy discontinuation. ${ }^{12}$ A gradual clearance of all lesions, both cutaneous and genital, was documented approximately 6 months after treatment initiation, while pruritus was also significantly improved. In the 15 -month follow-up visit, the patient showed no signs of relapse (figure 1B). The therapy was well tolerated, with no reported adverse reactions.

LSA is a chronic condition that affects mostly the anogenital region, but can also manifest in extragenital areas and can prove refractory to many topical and systemic treatments. ${ }^{34}$ Large scale studies on generalised extragenital disease are rather scarce, with case series and case reports being the source of information concerning the therapeutic approach in this case. ${ }^{1-4}$ Kreuter et al describe a prospective study of seven patients that showed sufficient response under a regimen with pulsed intravenous high-dose corticosteroids combined with orally administered low-dose methotrexate therapy $\left(15 \mathrm{mg}\right.$ weekly). ${ }^{3}$ A limited number of small studies and case series describe the administration of methotrexate as monotherapy. ${ }^{124}$ However, no studies concerning the use of high pulse intravenous steroids combined with topical potent

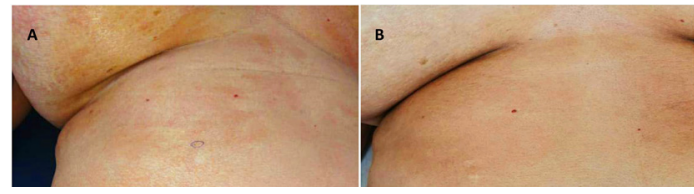

Figure 1 (A) Erythematous, brown and porcelainwhite patches with prominent epidermal atrophy of the abdominal and breast area. (B) Regression of lesions in the abdominal and breast area 15 months after cessation of treatment.

steroids are reported. The fact that our patient was overweight discouraged us from considering methotrexate as a treatment option, since patients with increased body mass index tend to be more susceptible to methotrexate-associated liver toxicity. ${ }^{5}$ The application of potent topical steroids in our case was limited to the genital lesions, as described above. A monotherapy with local steroids in all the lesionscutaneous and extracutaneous-would be an impractical and non-realistic option, first due to the extent of the extragenital involvement in our patient, and second due to the difficulty in estimating the exact systemic absorption of the medication. In conclusion, a pulse therapy with high-dose corticosteroids is a useful option for cases where other therapeutic regimes, such as potent topical steroids or methotrexate monotherapy, are either insufficient to achieve disease control, or contraindicated.

The purpose of this report is to point out that pulsed intravenous high-dose steroids, combined with topical steroid treatment is a safe and effective option for patients with both genital and generalised extragenital manifestations of LSA.

\section{Learning points}

The current guidelines suggest topical treatment with potent steroids as first-line therapy for genital lichen sclerosus et atrophicus (LSA). However, such option is not realistic in cases of generalised cutaneous LSA findings.

- A combination treatment of topical steroids and pulsed intravenous high-dose steroids is a safe and effective option for patients with both genital and extensive extragenital disease, who are unsuitable candidates for other long-term immunosuppressive treatments. 
Images in...

Contributors K-MP and SG had the idea of the study. K-MP, KG and FM prepared the manuscript. SG critically revised the manuscript. All authors accepted the final version of the manuscript.

Funding The authors have not declared a specific grant for this research from any funding agency in the public, commercial or not-for-profit sectors.

Competing interests None declared.

Patient consent for publication Obtained.

Provenance and peer review Not commissioned; externally peer reviewed.

\section{ORCID iDs}

Francesk Mulita http://orcid.org/0000-0001-7198-2628

Katerina Grafanaki http://orcid.org/0000-0002-6569-1928

\section{REFERENCES}

1 Lewis FM, Tatnall FM, Velangi SS, et al. British association of dermatologists guidelines for the management of lichen sclerosus, 2018. Br J Dermatol 2018;178:839-53.

2 Kirtschig G, Becker K, Günthert A, et al. Evidence-Based (S3) guideline on (anogenital) lichen sclerosus. J Eur Acad Dermatol Venereol 2015;29:e 1-43.

3 Kreuter A, Tigges C, Gaifullina R, et al. Pulsed high-dose corticosteroids combined with low-dose methotrexate treatment in patients with refractory generalized extragenital lichen sclerosus. Arch Dermatol 2009;145:1303-8.

4 Cuellar-Barboza A, Bashyam AM, Ghamrawi RI, et al. Methotrexate for the treatment of recalcitrant genital and extragenital lichen sclerosus: a retrospective series. Dermatol Ther 2020:33:e13473.

5 Shetty A, Cho W, Alazawi W, et al. Methotrexate hepatotoxicity and the impact of nonalcoholic fatty liver disease. Am J Med Sci 2017;354:172-81.

Copyright 2021 BMJ Publishing Group. All rights reserved. For permission to reuse any of this content visit

https://www.bmj.com/company/products-services/rights-and-licensing/permissions/

BMJ Case Report Fellows may re-use this article for personal use and teaching without any further permission.

Become a Fellow of BMJ Case Reports today and you can:

- Submit as many cases as you like

- Enjoy fast sympathetic peer review and rapid publication of accepted articles

- Access all the published articles

Re-use any of the published material for personal use and teaching without further permission

\section{Customer Service}

If you have any further queries about your subscription, please contact our customer services team on +44 (0) 2071111105 or via email at support@bmj.com.

Visit casereports.bmj.com for more articles like this and to become a Fellow 